\title{
Italian social psychiatry research: What gets published in peer reviewed journals?
}

\author{
GIAN MARIA GALEAZZI ${ }^{1}$ e STEFAN PRIEBE ${ }^{2}$ \\ ${ }^{1}$ East London \& the City University NHS Mental Health Trust, London (United Kingdom) \\ ${ }^{2}$ Queen Mary University of London, London (United Kingdom)
}

\begin{abstract}
SUMMARY. Aims - To explore the current state of Italian social psychiatry research as evidenced by original papers published in peer-reviewed journals 2004-2006. Methods - Electronic databases and hand searches of leading peer-reviewed journals were used to identify original research papers published in 2004-2006, addressing a social psychiatric issue, having at least one Italian author, and reporting data from Italian samples. Results - A total of 174 papers were identified. A substantial proportion reported findings of international collaborative research. Quantitative methods dominated, with 86 papers on cross-sectional surveys. Only 18 papers showed results of intervention trials with pre and post measures. Most common target group were psychiatric patients in community mental health services which featured in 93 papers. Conclusions - There is a critical mass of Italian social psychiatry research, dominated by a few research centres and with considerable amount of international collaboration. The findings of this survey might reflect the relative shortage of national funding for social psychiatry research.
\end{abstract}

Declaration of Interest: None.

KEY WORDS: social psychiatry, Italy, bibliometrics.

Received 13.04.2007 - Final version received 08.05.2007 - Accepted on 11.05.2007.

\section{IN'TRODUC'TION}

Italy has been widely regarded as one of the driving countries for mental health reforms and de-institutionalisation in Europe. The law 180 is still seen as a significant milestone of reforms towards community mental health care in the western world (de Girolamo et al., 2007).

The law 180 and subsequent reforms were based on a new ideology and pushed through by a sufficient political will. They were based on values and visions about how good mental health care should function. Since the 1970s, the situation has somewhat changed. In particular, we have entered the era of evidence based mental health care, and there is an expectation that future service development will be influenced by research evidence.

Research in this area is applied rather than fundamental research. It has to take into account specific national

Address for correspondence: Dr. G.M. Galeazzi, Newham Rehabilitation \& Recovery Team. East London \& the City University NHS Mental Health Trust, 150 High Street, Stratford, London E15 2NE (United Kingdom).

Fax: +440208221 7656

E-mail: gian.galeazzi@elcmht.nhs.uk traditions and features of the given health and social care system. Thus, there is a challenge to the national scientific community to provide research findings in social psychiatry which may - directly or in-directly - benefit mental health care in Italy.

Inspired by similar analyses of German social psychiatry research conducted by Angermeyer and his group some years ago (Angermeyer \& Winkler, 2001; Holzinger \& Angermeyer, 2002; 2003), we therefore aimed to explore the current state of social psychiatry research in Italy. This issue can be addressed from various methodological angles, and our approach was to review original research papers in the area published in peerreviewed journals between 2004 and 2006. This timeframe was chosen to assess the most recent publication output and obtain a comprehensive picture without including too large a number of papers so that the review remained manageable. The review specifically focused on a) the topics covered by the research, b) the type of methods used, and c) the institutional origin of the publications.

\section{METHODS}

For a paper to be included in this review, the following inclusion criteria were used:

Epidemiologia e Psichiatria Sociale, 16, 3, 2007 
a) published in years 2004 to 2006 ;

b) having the editorial status of an original paper (exceptions were made for short/brief reports with abstracts);

c) reporting data on Italian samples (of quantitative or qualitative nature, no matter if pooled with data from other countries) concerning adult or elderly populations;

d) having at least one Italian author individually mentioned in the list of authors (and not just as a member of a study group with collective authorship);

e) written in English or Italian;

f) published in English or Italian language peer-reviewed journals listed in the Appendix. The list includes the first 70 journals with highest Impact Factor of those listed by the Institute Scientific Information (ISI) Science Citation Index and in Social Science Citation Index for the discipline "Psychiatry" (reference year: 2004) and four Italian Journals included in the Psycinfo database of the American Psychological Association (Epidemiologia e Psichiatria Sociale, Minerva Psichiatrica, Rivista di Psichiatria, Rivista Sperimentale di Freniatria);

g) addressing a social psychiatry topic. For this we used the definition of social psychiatry by Priebe \& Hoffmann (2002) which was also applied by Holzinger \& Angermeyer (2003) in their analysis of German social psychiatry research. According to that definition, social psychiatry is a psychiatric discipline studying the social dimension of mental health and mental illness, and social factors in mental health care. It therefore includes psychiatric epidemiology; studies on the impact of life events and interpersonal relationships in psychiatry; attitudes and opinions of patients, mental health professionals and general population on mental illness and its care; research on milieu- and socio-therapeutic methods and specific long-term therapeutic concepts for chronically ill patients; and the evaluation of mental health care using objective and subjective outcome criteria (Priebe \& Hoffmann, 2002).

We therefore excluded:

a) studies published in supplements, as letters, editorials, case reports, reviews or metanalyses;

b) purely conceptual and methodological papers;

c) psychometric work, such as the construction or validation of rating scales (e.g., Becchi et al., 2004);

d) multicentre research where no Italian individual author was individually listed as author or co-author, although Italian authors may have been mentioned as members of a study group with collective authorship (e.g., Buist-Bouwman et al., 2006); e) studies merely describing services or therapeutic programmes;

f) historical papers;

g) studies dealing with the prevalence or risk of psychiatric disorders in specific physically ill populations;

h) research on children and young adolescent (below 18 years of age).

The main method to identify papers was a hand search and browsing of the online tables of contents of all considered journals for the years 2004 to 2006. This was complemented by MEDLINE and Psycinfo searches using as search terms the title of journal and search words "Italy" or "Italian". If doubts arose about the inclusion of a paper, the two authors discussed the paper and reached a consensus about its inclusion or exclusion. The following information was then systematically extracted from the identified papers: topic covered, population investigated/source of data, design/scope of research, institutional affiliation of authors.

\section{RESULTS}

A total of 174 papers were identified and included in the analysis. Of these, 115 appeared in international peerreviewed journals published in English, and 59 in the four Italian journals included. Figure 1 shows the selection process for papers for the review and the methods of research studies reported in the included papers.

Only a small number of studies employed qualitative research methods $(n=7,4 \%)$. The overwhelming majority applied quantitative methods with statistical analyses $(\mathrm{n}=167,96 \%)$. The design used in most cases was an observational cross-sectional survey (86 papers); 31 studies used a prospective observational design, whilst the analysis of administrative databases was used in 21 papers. Eighteen papers reported results on intervention trials with pre- and post-intervention measures of outcomes. Six of these studies were described as randomized controlled trials (Van Os et al., 2004; Gigantesco et al., 2006b; Gray et al., 2006; Magliano et al., 2006c; Slade et al., 2006; Veltro et al., 2006). Eleven studies, finally, were retrospective analyses of clinical charts.

Primary sources of data for most papers $(n=93)$ were psychiatric patients treated in community mental health services, followed by the general population $(n=20)$, staff of psychiatric services $(n=21)$, family or caregivers of patients $(n=16)$, at risk populations (Hardoy et al., 2005), patients seen by general practitioners $(n=7)$, patients with chronic medical illnesses $(n=2)$, prison inmates $(n=2)$,

Epidemiologia e Psichiatria Sociale, 16, 3, 2007 


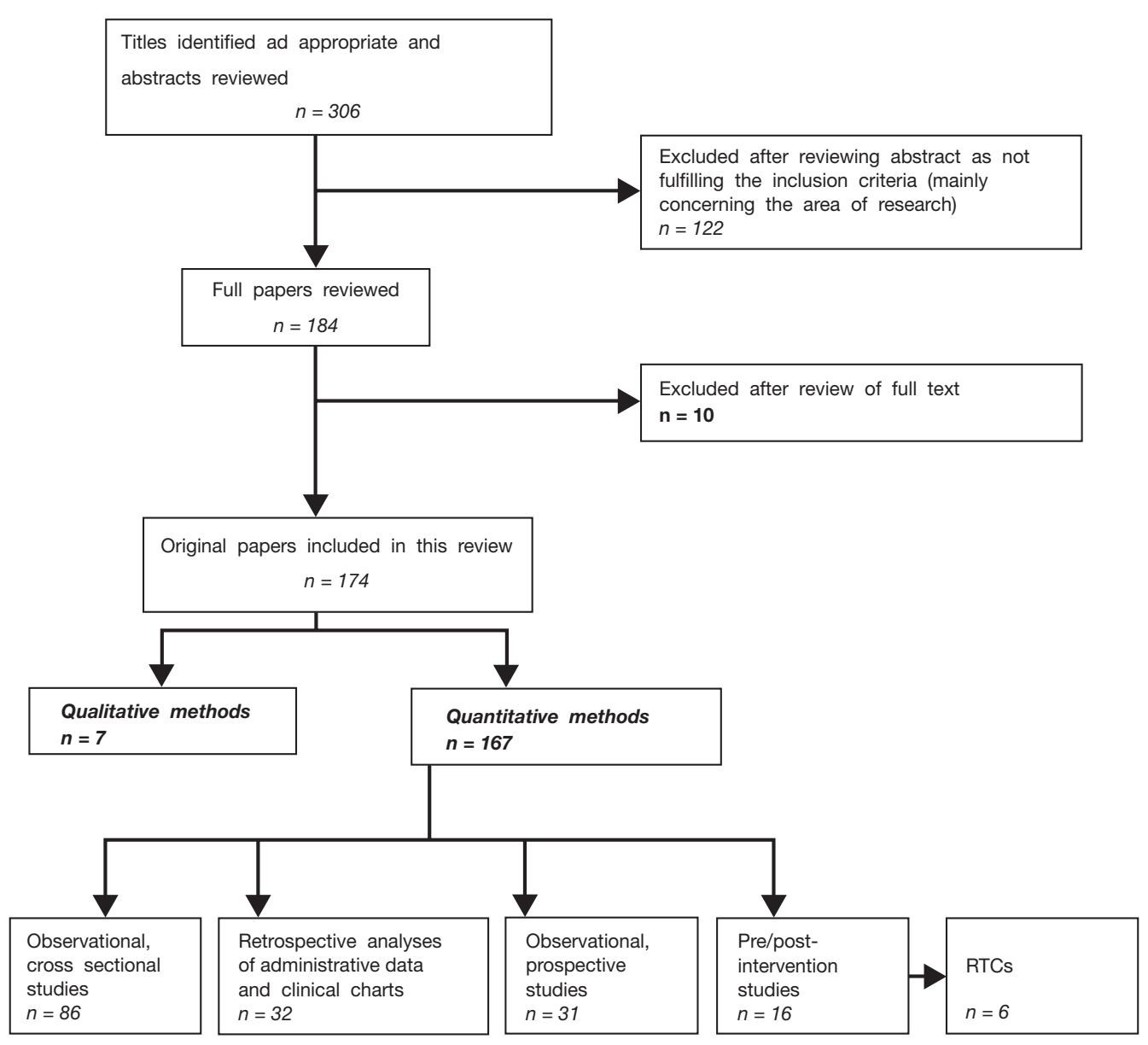

Figure 1. - Selection of papers for the review and methods of studied reported in included papers

elderly people in nursing homes $(\mathrm{n}=2)$, drug users $(\mathrm{n}=2)$, and other groups, e.g. police officers (Tomei et al., 2006); 21 papers reported descriptions and analyses of administrative datasets and official statistics.

With respect to the diagnostic groups studied, the single most often represented diagnostic group were patients with schizophrenia $(\mathrm{n}=28)$. A substantial number of papers $(\mathrm{n}=28)$, mainly observational naturalistic studies, reported on the clientele in public services, without limiting the type or severity of the disorder. Severe mental illness was the inclusion criterion, even when not explicitly mentioned, for the case-mix of further 20 papers (e.g. those studying samples in therapeutic residential facilities).

Patients with mood disorders were the subject of ten papers, four studied patients with anxiety disorders, three papers focused on patients with eating disorders. Other specific diagnostic groups were studied in fewer than three papers each (e.g. learning difficulties).

Regarding authorship and institutional affiliation, the majority of papers $(n=109)$ reported for the first author (or first listed Italian author in case of international multicentre studies) a university affiliation. The two most productive university centres were the Section of Psychiatry and Clinical Psychology of the University of Verona, followed by the Department of Psychiatry at the University of Naples, SUN. Further centres represented with more than four papers published in the period considered were the Department of Psychiatry of the Universities of Bologna, Cagliari, Ferrara, Florence, Roma "La Sapienza", and Turin. 36 manuscripts had a first Italian author affiliated with Local Health Agencies belonging to the National Health Service. The remaining 29 papers had as the first 
Table I. - Italian social psychiatry papers published 2004-2006: topics.

\begin{tabular}{|c|c|c|}
\hline \multirow{2}{*}{\multicolumn{3}{|c|}{ EPIDEMIOLOGY }} \\
\hline & & \\
\hline $\begin{array}{r}\text { Patterns and trends of prescriptions } \\
\text { of psychotropics }\end{array}$ & 17 & $\begin{array}{l}\text { (Barbui et al., 2004a, Percudani et al., 2004b, Percudani et al., 2004c, Andretta et al., 2005, } \\
\text { Barbui } \text { et al., 2005, Bargagli et al., 2005, Biancosino et al., 2005, Guaiana } \text { et al., 2005, } \\
\text { Pacitti et al., 2005, Percudani et al., 2005a, Percudani et al., 2005b, Pigato et al., 2005, } \\
\text { Tomasi et al., 2005, Barbui et al., 2006b, Barbui et al., 2006c, Percudani et al., 2006, } \\
\text { Tomasi et al., 2006) }\end{array}$ \\
\hline Prevalence/incidence of mental disorders & 10 & $\begin{array}{l}\text { (Battaglia } \text { et al., 2004, Demyttenaere } \text { et al., 2004, Faravelli } \text { et al., 2004a, Faravelli } \text { et al., } \\
\text { 2004b, De Ronchi } \text { et al., 2005b, Mangelli } \text { et al., 2005, Carta } \text { et al., 2006, de Girolamo } \text { et al., } \\
\text { 2006, Faravelli et al., 2006, Gigantesco et al., 2006a) }\end{array}$ \\
\hline Suicide & 8 & $\begin{array}{l}\text { (Dello Buono et al., 2004, Majori et al., 2004, Guaiana et al., 2005, Lorant et al., 2005, } \\
\text { Pavia et al., 2005, Zeppegno et al., 2005, Martiello et al., 2006, Scocco et al., 2006b) }\end{array}$ \\
\hline $\begin{array}{r}\text { Other (disorders in at-risk populations, } \\
\text { inmates) }\end{array}$ & 4 & (Carrà et al., 2004a, Farina et al., 2004, Bland et al., 2005, Bellomo et al., 2006) \\
\hline \multicolumn{3}{|c|}{ MENTAL HEALTH SERVICE RESEARCH } \\
\hline $\begin{array}{l}\text { Costs and funding of mental health } \\
\text { services and treatments }\end{array}$ & 11 & $\begin{array}{l}\text { (Barbui } \text { et al., 2004b, Garattini et al., 2004, Grigoletti et al., 2004, Mirandola et al., 2004, } \\
\text { Percudani et al., 2004a, Ruggeri et al., 2004a, Andretta et al., 2005, Burti et al., 2005, } \\
\text { Barbui et al., 2006a, Grigoletti et al., 2006, Slade } \text { et al., 2006) }\end{array}$ \\
\hline $\begin{array}{r}\text { Services utilisation, trends, determinants, } \\
\text { drop-out }\end{array}$ & 10 & $\begin{array}{l}\text { (Sangiorgio et al., 2004, Gaddini et al., 2005, Rossi et al., 2005a, Rossi et al., 2205b, } \\
\text { Salvador-Carulla et al., 2005, Tello et al., 2005a, Tello et al., 2005b, Menchetti et al., 2006, } \\
\text { Minnai } \text { et al., 2006, Rossi } \text { et al., 2006) }\end{array}$ \\
\hline Characterisation of services/mapping & 5 & $\begin{array}{l}\text { (de Girolamo et al., 2005, Salvador-Carulla } \text { et al., 2005, Santone } \text { et al., 2005, Picardi } \text { et al., } \\
\text { 2006a, Pozzi et al., 2006) }\end{array}$ \\
\hline $\begin{array}{r}\text { Analysis of macroindicators related } \\
\text { to mental health }\end{array}$ & 5 & $\begin{array}{l}\text { (Carta } \text { et al., 2004, Guaiana } \text { et al., 2005, Lorant } \text { et al., 2005, Priebe } \text { et al., 2005, Saxena } \text { et } \\
\text { al., 2006) }\end{array}$ \\
\hline Quality management/audit & 5 & $\begin{array}{l}\text { (Balestrieri et al., 2004, Pasquali et al., 2004, Abate et al., 2005, Allevi et al., 2006, Pozzi } \\
\text { et al., 2006) }\end{array}$ \\
\hline Deinstitutionalisation & 4 & (Barbato et al., 2004a, D’Avanzo et al., 2004, Priebe et al., 2005, Scocco et al., 2006a) \\
\hline \multicolumn{3}{|l|}{ OUTCOME RESEARCH } \\
\hline Disability/social functioning & 26 & $\begin{array}{l}\text { (Barbato et al., 2004a, Bellino et al., 2004, Lasalvia et al., 2004, Lora et al., 2004, Mazza } \\
\text { et al., 2004, Pallanti et al., 2004, Quaglio et al., 2004, Ruggeri et al., 2004a, Ruggeri et al., } \\
\text { 2004b, Ruggeri et al., 2004c, Slade et al., 2004, Thornicroft et al., 2004, Becker } \text { et al., 2005, } \\
\text { De Ronchi et al., 2005a, Gaite et al., 2005, Rocca et al., 2005, Ruggeri et al., 2005, } \\
\text { Scuccimarra et al., 2005, Bellomo et al., 2006, Farina et al., 2006, Gigantesco et al., 2006b, } \\
\text { Haro et al., 2006, Magliano et al., 2006c, Parabiaghi } \text { et al., 2006, Schiavone } \text { et al., 2006, } \\
\text { Veltro } \text { et al., 2006) }\end{array}$ \\
\hline Psychopathology & 22 & $\begin{array}{l}\text { (Barbato et al., 2004a, Bellino et al., 2004, Lasalvia et al., 2004, Lora et al., 2004, Ruggeri } \\
\text { et al., 2004a, Ruggeri et al., 2004b, Ruggeri et al., 2004c, Slade } \text { et al., 2004, de Girolamo } \\
\text { et al., 2005, Lasalvia et al., 2005, Rocca } \text { et al., 2005, Ruggeri } \text { et al., 2005, Scoscia et al., } \\
\text { 2005, Barbui et al., 2006b, Bellomo et al., 2006, Fassone et al., 2006, Gray et al., 2006, } \\
\text { Magliano et al., 2006a, Magliano et al., 2006c, Pozzi et al., 2006, Puschner } \text { et al., 2006, } \\
\text { Schiavone } \text { et al., 2006) }\end{array}$ \\
\hline Quality of life & 21 & $\begin{array}{l}\text { (Alonso et al., 2004, Barbato et al., 2004b, Bellino et al., 2004, Lasalvia et al., 2004, Lora } \\
\text { et al., 2004, Morselli et al., 2004, Ruggeri et al., 2004a, Ruggeri et al., 2004b, Ruggeri et } \\
\text { al., 2004c, Slade } \text { et al., 2004, Thornicroft et al., 2004, Becker et al., 2005, Lasalvia et al., } \\
\text { 2005, Rocca et al., 2005, Ruggeri et al., 2005, Soscia et al., 2005, Gray et al., 2006, Picardi } \\
\text { et al., 2006b, Puschner } \text { et al., 2006, Scocco et al., 2006a, Slade et al., 2006) }\end{array}$ \\
\hline \multirow[t]{2}{*}{$\begin{array}{r}\text { Efficacy/effectiveness of specific } \\
\text { interventions }\end{array}$} & 18 & $\begin{array}{l}\text { (Biffi et al., 2004, Bressi et al., 2004, Di Giannantonio et al., 2004, Lora } \text { et al., 2004, Mazza } \\
\text { et al., 2004, Van Os et al., 2004, Burti et al., 2005, Soscia et al., 2005, Veltro et al., 2005a, } \\
\text { Biancosino et al., 2006, Farina et al., 2006, Gigantesco et al., 2006b, Gray et al., 2006, } \\
\text { Magliano et al., 2006a, Magliano et al., 2006c, Scarnera } \text { et al., 2006, Slade et al., 2006, } \\
\text { Veltro et al., 2006) }\end{array}$ \\
\hline & 11 & $\begin{array}{l}\text { (Meijer } \text { et al., 2004, Ruggeri et al., 2004b, Slade } \text { et al., 2004, Van Os et al., 2004, Thornicroft } \\
\text { et al., 2004, Becker } \text { et al., 2005, Burti et al., 2005, Kovess } \text { et al., 2005, Lasalvia } \text { et al., 2005, } \\
\text { Rimondini } \text { et al., 2006, Slade } \text { et al., 2006) }\end{array}$ \\
\hline Satisfaction with service/treatment & 10 & $\begin{array}{l}\text { (Buscaglia et al., 2004, Gigantesco et al., 2004, Morselli et al., 2004, Ruggeri et al., 2004a, } \\
\text { Ruggeri et al., 2004c, Thornicroft et al., 2004, Biancosino et al., 2005, Ruggeri et al., 2005, } \\
\text { Veltro et al., 2005a, Ruggeri et al., 2006) }\end{array}$ \\
\hline
\end{tabular}




\begin{tabular}{|c|c|c|}
\hline & $\mathbf{N}^{\circ}$ & REFERENCES \\
\hline \multicolumn{3}{|l|}{ EPIDEMIOLOGY } \\
\hline Other outcome & 13 & $\begin{array}{l}\text { (Barbato et al., 2004a, Robone et al., 2004, Ruggeri et al., 2004a, Di Michele } \text { et al., } 2005 \\
\text { Gaddini } \text { et al., 2005, Magliano et al., 2005a, Parabiaghi et al., 2005, Scuccimarra et al., } 2005 \\
\text { Zanetti } \text { et al., 2005, Fassone } \text { et al., 2006, Haro } \text { et al., 2006, Lazzerini } \text { et al., 2006, Melon } \\
\text { et al., 2006) }\end{array}$ \\
\hline \multicolumn{3}{|l|}{ OTHER } \\
\hline Family/carers' burden & 12 & $\begin{array}{l}\text { (Lora et al., 2004, Magliano et al., 2004d, Meijer et al., 2004, Trequattrini et al., } 2004 \\
\text { Magliano et al., 2005a, Rinaldi et al., 2005, Ferruzza et al., 2006, Magliano et al., 2006a } \\
\text { Magliano et al., 2006c, Magliano et al., 2006d, Tarricone } \text { et al., 2006, Veltro et al., 2006) }\end{array}$ \\
\hline Impact of psychosocial factors on mental & 12 & $\begin{array}{l}\text { (Faravelli et al., 2004c, Lo Baido et al., 2004, Marchiori et al., 2004, Albert et al., } 2005 \\
\text { Bland et al., 2005, Hardoy et al., 2005, Berti et al., 2006, Carta et al., 2006, Favaro et al. } \\
\text { 2006, Grava et al., 2006, Preti et al., 2006, Tomei et al., 2006) }\end{array}$ \\
\hline Users' experiences and opinions & 7 & $\begin{array}{l}\text { (Biancosino et al., 2004, Bonner } \text { et al., 2004, Burti et al., 2004, Gigantesco et al., } 2004 \\
\text { Marmai } \text { et al., 2005, Marin \& Mezzina 2006, Paccaloni } \text { et al., 2006) }\end{array}$ \\
\hline \multirow{2}{*}{$\begin{array}{r}\text { Collaboration with GPs (recognition of } \\
\text { disorders, appropriateness of referral } \\
\text { and prescription) }\end{array}$} & 7 & $\begin{array}{l}\text { (Balestrieri et al., 2004, Saltini et al., 2004, Balestrieri et al., 2005, Berardi et al., 2005, Di } \\
\text { Pietro et al., 2005, Calogiuri et al., 2006, Menchetti } \text { et al., 2006) }\end{array}$ \\
\hline & 7 & $\begin{array}{l}\text { (Galeazzi } \text { et al., 2004, Freilone } \text { et al., 2005, Pizzichi } \text { et al., 2005, Zammuner \& Galli, } 2005 \\
\text { Lalli } \text { et al., 2006, Pompili } \text { et al., 2006, Scarnera } \text { et al., 2006) }\end{array}$ \\
\hline Attitudes and beliefs about mental illness & 5 & $\begin{array}{l}\text { (Magliano et al., 2004a, Magliano et al., 2004b, Magliano et al., 2004c, Buizza et al., } 2005 \\
\text { Veltro et al., 2005b) }\end{array}$ \\
\hline Aggression and violence & 5 & $\begin{array}{l}\text { (Vanni et al., 2004, Bowers et al., 2005, Fasanelli et al., 2006, Fioritti et al., 2006, Grassi } \\
\text { et al., 2006) }\end{array}$ \\
\hline Adherence & 4 & (Fasanelli et al., 2006, Gray et al., 2006, Kikkert et al., 2006, Puschner et al., 2006) \\
\hline Ward atmosphere & 3 & (Burti et al., 2004, Carrà et al., 2004b, Di Lorenzo et al., 2005) \\
\hline Training of staff & 3 & (Magliano et al., 2005a, Magliano et al., 2005b, Magliano et al., 2006b) \\
\hline Therapeutic alliance & 2 & (Van Weeghel et al., 2005, Slade et al., 2006) \\
\hline Transcultural psychiatry & 2 & (Lo Baido et al., 2004, Carta et al., 2006) \\
\hline
\end{tabular}

Italian author mainly members of other research institutions, such as the Istituto Superiore di Sanità (National Health Research Institute) and the Mario Negri Institute, various IRCCS (Istituti di Ricovero e Cura a Carattere Scientifico = Scientific Institutes for Research, Hospitalisation and Health Care) and Regional Health Agencies.

Among the included journals the following ones published more than 5 original research papers in social psychiatry with an Italian author: Rivista di Psichiatria $(\mathrm{n}=24)$, Epidemiologia e Psichiatria Sociale $(\mathrm{n}=21)$, Social Psychiatry and Psychiatric Epidemiology $(\mathrm{n}=20)$, Psychotherapy and Psychosomatics $(\mathrm{n}=8)$, British Journal of Psychiatry (n=6), Psychiatric Services $(\mathrm{n}=6)$, Psichiatria e Psicoterapia $(\mathrm{n}=6)$, Minerva Psichiatrica $(\mathrm{n}=6)$, Internatonal Journal of Geriatric Psychiatry $(\mathrm{n}=5)$, International Clinical Psychopharmacology $(\mathrm{n}=5)$.

\section{DISCUSSION}

Whether the total number of 174 papers is regarded as substantial or not, depends on the perspective. We have not conducted the same analysis for other countries, but it might be safe to assume that the number is much smaller than that of the papers published in the United Kingdom and United States, but probably higher than that in some other European countries. In any case, the number shows that social psychiatry research in Italy is very much alive and productive. There is a critical mass of research production, which finds recognition not only in national papers, but even more so in international journals.

In any interpretation of the findings of this review, the limitations of the method should be considered. Our criteria to include journals and papers had a degree of arbitrariness. The decision on the inclusion or exclusion of specific journals and the classification of many single papers can be seen as questionable. Thus, there is a risk that we overlooked or mis-classified important papers. Also, we took papers at face value and did not critically appraise them applying quality criteria. Finally, publications report results of completed studies and there is an inevitable time lag between research production and publications. Our review subsequently reflects the research conducted a few years ago, whilst the current picture 
which will be shown in publications in a few years time might already be different.

The focus on peer-reviewed publications was operationalised and is replicable to assess changes over time. It reflects the performance criteria of the academic world in which peer-reviewed publications - along with competitive grant income - are what counts for success. Complex bibliometric assessments are of course possible and there is a rich debate on how best to assess the value of psychiatric research (Lewison et al., 2007). However, peerreviewed publications are an important criterion in practically every exercise evaluating research performance.

A few centres dominate the output of Italian social psychiatry research. The dominance of a relatively small number of centres can be found in most countries and might not been seen as a problem as long as the overall critical mass is sufficient to generate competition and quality. Despite the dominance of a few centres, the number of authors is substantial. They are based in different regions and affiliated with a wide range of academic and non-academic institutions. Thus, there appear to be a wide spread interest and capacity to conduct and publish social psychiatry research which is not limited to main academic centres.

Much of the research is conducted in international collaboration. Italian social psychiatry researchers seem to be valued as partners in multi-centre studies and contribute on a practical and scientific level. There is a paucity of randomised controlled studies of interventions. We found only two randomised controlled national multi-centre trials: one testing a structured rehabilitation programme (Gigantesco et al., 2006b), and the other one a psycho-educational intervention for families of patients with schizophrenia (Magliano et al., 2006c). Some more single centre trials were conducted, regularly without substantial external funding and using local resources. Two of them dealt with family interventions and the exploration of family and carers' burden featured in twelve papers. The relative frequency of such studies might be regarded as a specific feature of Italian psychiatry and a potential strength in an international research competition.

Intervention studies usually take several years and absorb significant amounts of funding. It is therefore not surprising that only a small percentage of papers report results of such studies. However, the fact that there are only two national multicentre trials raises questions about the reasons. Lack of expertise can hardly be the main factor, since many researchers successfully provide such expertise in international studies. The shortage of intervention studies might be better explained by the absence of specific and substantial national funding programmes for such research. In the United Kingdom there have been significant targeted funding programmes for national studies in mental health service research, and in Germany corresponding programmes have recently been initiated. In Italy, such funding programmes with regular national calls for applications either do not exist or are difficult to access. The recent initiative of the Ministry of Health to fund national targeted research activities may help to strengthen mental health service research, but is unlikely to alter the problem of insufficient funding completely. Subsequently, researchers have to tap into international funds, which is a naturally limited approach, utilise regional budgets, which are usually not sufficient to fund large trials, and - most importantly - improvise with ownaccount studies. The PROGRES project, surveying provision, features and outcomes in Italian residential facilities, of which the main publications appeared in the period considered (de Girolamo et al., 2005; Santone et al., 2005; Picardi et al., 2006a, b; Tomasi et al., 2006), showed that it is possible to create a network of committed researchers from different backgrounds and thus deliver a large and rigorous research project without large external grants. Several other small scale studies are also witness to the abilities of researchers at Italian universities and services to conduct research with limited funding. Yet, for a lasting improvement of social psychiatric research and its output, the position of social psychiatry research in the national arena must be strengthened and specific funding programmes are required. In this context, it may be noted that the innovative research funding experience coordinated by the National Health Research Institute in years 1997-2001, the National Mental Health Project (Morosini et al., 2001) has not yet seen further editions.

Over the last five to ten years, qualitative research has internationally become more popular in social psychiatry. This is not yet reflected in the publications from Italy of the last three years. Perhaps, this is an area in which specific efforts of one or two centres might bare fruits relatively soon. There is no obvious reason why Italy should not be able to compete in qualitative research on a high level.

\section{CONCLUSIONS}

The method of this review has strengths and limitations, but the findings clearly show that social psychiatry research in Italy is active and produces internationally acknowledged results. The strong international collaboration is associated with a relatively small focus on specific

Epidemiologia e Psichiatria Sociale, 16, 3, 2007 
Italian issues and a wide acceptance of Anglo-American concepts and methods, which might not always be appropriate for the Italian situation. There are only a few aspects in which Italian social psychiatry makes a specific contribution. One example is research on family interventions.

Our review started from the assumption that research may influence service development and identified numbers of publications with relevant topics. However, the ultimate criterion for the value of research can hardly be the number of publications, but rather the impetus for service development and the benefit to patients in Italy. This, however, is much more difficult to measure than mere numbers of papers.

\section{Appendix: Journals considered in this review:}

Academic Psychiatry, Acta Psychiatrica Scandinavica, Addiction, Aging \& Mental Health, American Journal of Geriatric Psychiatry, American Journal of Orthopsychiatry, American Journal of Psychiatry, Anxiety, Stress and Coping, Archives of Psychiatric Nursing, Archives of General Psychiatry, Australian and New Zealand Journal of Psychiatry, Behavioral Medicine, Biological Psychiatry, Bipolar Disorders, British Journal of Psychiatry, BMJ, Bulletin of the Menninger Clinic, Canadian Journal of Psychiatry, Community Mental Health Journal, Comprehensive Psychiatry, Contemporary Psychoanalysis, Culture Medicine and Psychiatry, Current Opinion in Psychiatry, Dementia and Geriatric Cognitive Disorders, Depression and Anxiety, Drug and Alcohol Dependence, Epidemiologia e Psichiatria Sociale, Epilepsy and Behavior, European Archives of Psychiatry and Clinical Neuroscience, European Neuropsychopharmacology, European Psychiatry, Experimental and Clinical Psychopharmacology, General Hospital Psychiatry, Harvard Review of Psychiatry, Human PsychopharmacologyClinical and Experimental, International Clinical Psychopharmacology, International Journal of Clinical and Experimental Hypnosis, International Journal of Eating Disorders, International Journal of Geriatric Psychiatry, International Journal of Law and Psychiatry, International Journal of Methods in Psychiatric Research, International Journal of Neuropsychopharmacology, International Journal of Psychiatry in Medicine, International Journal of Social Psychiatry, International Psychogeriatrics, International Review of Psychiatry, Journal of Affective Disorders, Journal of the American Academy of Psychiatry and the Law, JAMA, Journal of the American Psychoanalitic Association, Journal of Anxiety Disorders, Journal of Behavior Therapy and Experimental Psychiatry, Journal of Clinical Psychiatry, Journal of Clinical Psychophamacology, Journal of ECT, Journal of Forensic Psychiatry and Psychology, Journal of Geriatric Psychiatry and Neurology, Journal of the International Neuropsychological Society, Journal of Nervous and Mental Disease, Journal of Neuropsychiatry and Clinical Neurosciences, Journal of Personality Disorders, Journal of Psychiatric Research, Journal of Psychiatry and Neuroscience, Journal of Psychopharmacology, Journal of Psychosomatic Obstetrics and Gynecology, Journal of Psychosomatic Research, Journal of Traumatic Stress, Minerva Psichiatrica,Molecular Psychiatry, Neurocase, Neuropsychiatry, Neuropsychobiology, Neuropsychology and Behavioral Neurology, Journal of Neurology, Neurosurgery and Psychiatry, Neuropsychophamacology, Nordic Journal of Psychiatry, Perspectives in Psychiatric Care, Pharmacopsychiatry, Progress in NeuroPsychopharmacology \& Biological Psychiatry, Psichiatria e
Psicoterapia, Psychiatric Annals, Psychiatric Clinics of North America, Psychiatric Quarterly, Psychiatric Rehabilitation Journal, Psychiatric Services, Psychiatry, Psychiatry and Clinical Neurosciences, Psychiatry Research, Psychiatry Research-Neuroimaging, Psychological Medicine, Psychopathology, Psychopharmacology, Psychosomatic Medicine, Psychosomatics, Psychotherapy and Psychosomatics, Quality of Life Research, Rivista di Psichiatria, Rivista Sperimentale di Freniatria, Schizophrenia Bulletin, Schizophrenia Research, Sleep, Social Psychiatry and Psychiatric Epidemiology, Social Science and Medicine, Stress and Health, Suicide and Life-Threatening Behavior.

\section{REFERENCES}

Abate S., D'amato A., Belpedio D. \& Ventra D. (2005). Un indicatore di valutazione di qualità per una casa di cura psichiatrica convenzionata. Rivista di Psichiatria 40, 291-299.

Albert U., Maina G., Bergesio C. \& Bogetto F. (2005). Nocturnal panic and recent life events. Depression and Anxiety 22, 52-58.

Allevi L., Salvi G. \& Ruggeri M. (2006). La qualita dei servizi di salute mentale: un esercizio di autovalutazione nel servizio psichiatrico di Verona Sud.[Quality of mental health services: a self audit in the South Verona mental health service]. Epidemiologia e Psichiatria Sociale 15, 138-147.

Alonso J., Ferrer M., Gandek B., Ware J. E., Jr., Aaronson N. K., Mosconi P., Rasmussen N. K., Bullinger M., Fukuhara S., Kaasa S. \& Leplege A. (2004). Health-related quality of life associated with chronic conditions in eight countries: Results from the International Quality of Life Assessment (IQOLA) Project. Quality of Life Research 2, 283-298.

Andretta M., Ciuna A., Corbari L., Cipriani A. \& Barbui C. (2005). Impact of regulatory changes on first- and second-generation antipsychotic drug consumption and expenditure in Italy. Social Psychiatry and Psychiatric Epidemiology 40, 72-77.

Angermeyer M. C. \& Winkler I. (2001). Wer, was, wie viel, wo? Eine Analyse der Publikationen deutscher Autoren zu sozialpsychiatrischen Themen in wissenschaftlichen Zeitschriften [Who, What, How much, Where? - an analysis of publications by German authors on sociopsychiatric issues in scientific journals]. Psychiatrische Praxis 28, 368-375.

Balestrieri M., Carta M. G., Leonetti S., Sebastiani G., Starace F. \& Bellantuono C. (2004). Recognition of depression and appropriateness of antidepressant treatment in Italian primary care. Social Psychiatry and Psychiatric Epidemiology 39, 171-176.

Balestrieri M., Marcon G., Samani F., Marini M., Sessa E., Gelatti U. \& Donato F. (2005). Mental disorders associated with benzodiazepine use among older primary care attenders A regional survey. Social Psychiatry and Psychiatric Epidemiology 40, 308-315.

Barbato A., D’Avanzo B., Rocca G., Amatulli A. \& Lampugnani D. (2004a). A study of long-stay patients resettled in the community after closure of a psychiatric hospital in Italy. Psychiatric Services 55, 67-70.

Barbato A., Monzani E. \& Schiavi T. (2004b). Life satisfaction in a sample of outpatients with severe mental disorders: A survey in northern Italy. Quality of Life Research 13, 969-973.

Barbui C., Ciuna A., Nose M., Patten S. B., Stegagno M., Burti L., Amaddeo F. \& Tansella M. (2004a). Off-label and non-classical prescriptions of antipsychotic agents in ordinary in-patient practice. Acta Psychiatrica Scandinavica 109, 275-278.

Barbui C., Garattini L., Krulichova I., Apolone G., Negri E. \& Ricci E. (2004b). Health status, resource consumption, and costs of dysthymic patients in Italian primary care. Epidemiologia e Psichiatria Sociale 13, 120-125.

Barbui C., Ciuna A., Nose M., Levi D., Andretta M., Patten S. B., Amaddeo F. \& Tansella M. (2005). Drug treatment modalities in 
psychiatric inpatient practice: a 20-year comparison. European Archives of Psychiatry and Clinical Neuroscience 255, 136-142.

Barbui C., Motterlini N. \& Garattini L. (2006a). Health status, resource consumption, and costs of dysthymia. A multi-center two-year longitudinal study. Journal of Affective Disorders 90, 181-186.

Barbui C., Nose M., Mazzi M. A., Bindman J., Leese M., Schene A., Becker T., Angermeyer M. C., Koeter M., Gray R. \& Tansella M. (2006b). Determinants of first- and second-generation antipsychotic drug use in clinically unstable patients with schizophrenia treated in four European countries. International Clinical Psychopharmaco$\log y$ 21, 73-79.

Barbui C., Nose M., Mazzi M. A., Thornicroft G., Schene A., Becker T., Bindman J., Leese M., Helm H., Koeter M., Weinmann S. \& Tansella M. (2006c). Persistence with polypharmacy and excessive dosing in patients with schizophrenia treated in four European countries. International Clinical Psychopharmacology 21, 355-362.

Bargagli A. M., Schifano P., Davoli M., Faggiano F., Perucci C. A. \& Versino E. (2005). Determinants of methadone treatment assignment among heroin addicts on first admission to public treatment centres in Italy. Drug and Alcohol Dependence 79, 191-199.

Battaglia A., Dubini A., Mannheimer R. \& Pancheri P. (2004). Depression in the Italian community: epidemiology and socio-economic implications. International Clinical Psychopharmacology 19, 135-142.

Becchi A., Rucci P., Placentino A., Neri G. \& de Girolamo G. (2004). Quality of life in patients with schizophrenia--comparison of selfreport and proxy assessments. Social Psychiatry and Psychiatric Epidemiology 39, 397-401.

Becker T., Leese M., Krumm S., Ruggeri M. \& Vazquez-Barquero J. L. (2005). Needs and quality of life among patients with schizophrenia in five European centres: what is the impact of global functioning scores? Social Psychiatry and Psychiatric Epidemiology 40, 628634.

Bellino S., Rocca P., Patria L., Marchiaro L., Rasetti R., Di Lorenzo R., Paradiso E. \& Bogetto F. (2004). Relationships of Age at Onset With Clinical Features and Cognitive Functions in a Sample of Schizophrenia Patients. Journal of Clinical Psychiatry 65, 908-914.

Bellomo A., De Giorgi A., Petito A., Cammeo C., Lepore A., Borrelli A. \& Nardini M. (2006). Il disturbo post-traumatico da stress come conseguenza di gravi incidenti stradali [Post-traumatic stress disorder as a consequence of severe road traffic accidents]. Minerva Psichiatrica 47, 155-164.

Berardi D., Menchetti M., Cevenini N., Scaini S., Versari M. \& De Ronchi D. (2005). Increased recognition of depression in primary care. Comparison between primary-care physician and ICD-10 diagnosis of depression. Psychotherapy and Psychosomatics 74, 225230.

Berti A., Fizzotti C., Maberino C. \& Zanelli E. (2006). Impatto dello stalking sulle vittime: rilievo epidemiologico sul fenomeno nella città di Genova. Rivista di Psichiatria 41, 241-249.

Biancosino B., Barbui C., Marmai L., Dona S. \& Grassi L. (2005). Determinants of antipsychotic polypharmacy in psychiatric inpatients: a prospective study. International Clinical Psychopharmaco$\operatorname{logy} 20,305-309$.

Biancosino B., Barbui C., Pera V., Osti M., Rocchi D., Marmai L. \& Grassi L. (2004). Patient opinions on the benefits of treatment programs in residential psychiatric care. Canadian Journal of Psychiatry 49, 613-620.

Biancosino B., Rocchi D., Dona S., Kotrotsiou V., Marmai L. \& Grassi L. (2006). Efficacy of a short-term psychoeducational intervention for persistent non-organic insomnia in severely mentally ill patients. A pilot study. European Psychiatry 21, 460-462.

Biffi G., Cella M. \& Amigoni C. (2004). Progetto Vita: limiti e pregi della sua applicabilità in un servizio psichiatrico territoriale. [Life project: limits and benefits in a psychiatric community service]. Rivista di Psichiatria 2004, 258-264.

Bland S. H., Valoroso L., Stranges S., Strazzullo P., Farinaro E. \& Trevisan M. (2005). Long-term follow-up of psychological distress following earthquake experiences among working Italian males: a cross-sectional analysis. Journal of Nervous and Mental Disease 193, 420-423.

Bonner Y. D. B., Andreoli M. V., Lemmi M., Garamante M., Pellegrino R. \& Poziello F. (2004). Farmaco Buono o Cattivo? Opinioni di un gruppo di familiari e di utenti [Are drugs good or bad? Patients and families opinions]. Rivista Sperimentale di Freniatria 128, 111-131.

Bowers L., Douzenis A., Galeazzi G. M., Forghieri M., Tsopelas C., Simpson A. \& Allan T. (2005). Disruptive and dangerous behaviour by patients on acute psychiatric wards in three European centres. Social Psychiatry and Psychiatric Epidemiology 40, 822-828.

Bressi C., Lo Baido R., Manenti S., Frongia P., Guidotti B., Maggi L., Merati O., Giordano P. \& Invernizzi G. (2004). Efficacia clinica della terapia familiare sistemica nella schizofrenia: uno studio prospettico longitudinale [Schizophrenia and the clinical efficacy of the systemic family therapy: a prospectic longitudinal study]. Rivista di Psichiatria 39, 189-197.

Buist-Bouwman M. A., De Graaf R., Vollebergh W. A., Alonso J., Bruffaerts R., Ormel J. \& Investigators E. M. (2006). Functional disability of mental disorders and comparison with physical disorders: a study among the general population of six European countries. Acta Psychiatrica Scandinavica 113, 492-500.

Buizza C., Pioli R., Ponteri M., Vittorielli M., Corradi A., Minicuci N. \& Rossi G. (2005). Atteggiamenti verso la malattia mentale e caratteristiche socio-demografiche: uno studio in una citta del nord Italia.[Community attitudes towards mental illness and socio-demographic characteristics: an Italian study]. Epidemiologia $e$ Psichiatria Sociale 14, 154-162.

Burti L., Andreone N. \& Mazzi M. (2004). Reassessing treatment environments after two decades: client and staff perceptions of an Italian Community Mental Health Service environment, then and now. Community Mental Health Journal 40, 199-210.

Burti L., Amaddeo F., Ambrosi M., Bonetto C., Cristofalo D., Ruggeri M. \& Tansella M. (2005). Does additional care provided by a consumer self-help group improve psychiatric outcome? A study in an Italian community-based psychiatric service. Community Mental Health Journal 41, 705-720.

Buscaglia G., Carolei A., Baldazzi F., Marinoni A. \& Ferro A. M. (2004). Rilevare la soddisfazione dei pazienti e dei familiari: l'esperienza del Dipartimento di Salute Mentale di Savona. [Surveying patients' and family members' satisfaction: the experience of the Mental Health Department in Savona]. Epidemiologia e Psichiatria Sociale 13, 158-168.

Calogiuri V., Magnavita N. \& Angelozzi A. (2006). Analisi degli invii dei medici di Medicina Generale ad un Ambulatorio di Salute Mentale: uno studio esplorativo [Analyses of General Practitioners' referral to Mental Health Centre: a survey]. Minerva Psichiatrica 47, 199-208.

Carrà G., Giacobone C., Pozzi F., Alecci P. \& Barale F. (2004a). Prevalenza di disturbi mentali e trattamenti correlati in una casa circondariale: uno studio di 20 mesi di casi consecutivi. [Prevalence of mental disorder and related treatments in a local jail: a 20-month consecutive case study]. Epidemiologia e Psichiatria Sociale 13, 47-54.

Carrà G., Giroletti A., Scioli R. \& Barale F. (2004b). Ward atmosphere in a psychiatric inpatient service in Italy. Minerva Psichiatrica 45, 133-140.

Carta M. G., Kovess V., Hardoy M. C., Brugha T., Fryers T., Lehtinen V. \& Xavier M. (2004). Psychosocial wellbeing and psychiatric care in the European Communities: analysis of macro indicators. Social Psychiatry and Psychiatric Epidemiology 39, 883-892.

Carta M. G., Reda M. A., Consul M. E., Brasesco V., CetkovichBakmans M. \& Hardoy M. C. (2006). Depressive episodes in Sardinian emigrants to Argentina: why are females at risk? Social Psychiatry and Psychiatric Epidemiology 41, 452-456.

D’Avanzo B., Battino R. N., Gallus S. \& Barbato A. (2004). Factors predicting discharge of patients from community residential facilities: A longitudinal study from Italy. Australian and New Zealand Journal of Psychiatry 38, 619-628. 
de Girolamo G., Picardi A., Santone G., Falloon I., Morosini P., Fioritti A. \& Micciolo R. (2005). The severely mentally ill in residential facilities: a national survey in Italy. Psychological Medicine 35, 421-431.

de Girolamo G., Polidori G., Morosini P., Scarpino V., Reda V., Serra G., Mazzi F., Alonso J., Vilagut G., Visona G., Falsirollo F., Rossi A. \& Warner R. (2006). Prevalence of common mental disorders in Italy: Results from the European Study of the Epidemiology of Mental Disorders (ESEMeD). Social Psychiatry and Psychiatric Epidemiology 41, 853-861.

de Girolamo G., Bassi M., Neri G., Ruggeri M., Santone G. \& Picardi A. (2007). The current state of mental health care in Italy: problems, perspectives, and lessons to learn. European Archives of Psychiatry and Clinical Neurosciences 257, 71-82.

De Ronchi D., Bellini F., Berardi D., Serretti A., Ferrari B. \& Dalmonte E. (2005a). Cognitive status, depressive symptoms, and health status as predictors of functional disability among elderly persons with low-to-moderate education: the Faenza community aging study. American Journal of Geriatric Psychiatry 13, 672-685.

De Ronchi D., Berardi D., Menchetti M., Ferrari G., Serretti A., Dalmonte E. \& Fratiglioni L. (2005b). Occurrence of cognitive impairment and dementia after the age of 60: a population-based study from Northern Italy. Dementia and Geriatric Cognitive Disorders 19, 97-105.

Dello Buono M., Darù E., Colucci E. \& Pavan L. (2004). Predittori di rischio suicidario nelle diverse età della vita: uno studio su 511 suicidi [Predictors of suicide risk across the life cycle: a study of 511 suicides]. Rivista di Psichiatria 39, 340-348.

Demyttenaere K., Bruffaerts R., Posada-Villa J., Gasquet I., Kovess V., Lepine J. P., Angermeyer M. C., Bernert S., de Girolamo G., Morosini P., Polidori G., Kikkawa T., Kawakami N., Ono Y., Takeshima T., Uda H., Karam E. G., Fayyad J. A., Karam A. N., Mneimneh Z. N., Medina-Mora M. E., Borges G., Lara C., De Graaf R., Ormel J., Gureje O., Shen Y., Huang Y., Zhang M., Alonso J., Haro J. M., Vilagut G., Bromet E. J., Gluzman S., Webb C., Kessler R. C., Merikangas K. R., Anthony J. C., Von Korff M. R., Wang P. S., Brugha T. S., Aguilar-Gaxiola S., Lee S., Heeringa S., Pennell B. E., Zaslavsky A. M., Ustun T. B. \& Chatterji S. (2004). Prevalence, severity, and unmet need for treatment of mental disorders in the World Health Organization World Mental Health Surveys. Journal of the American Medical Association 291, 2581-2590.

Di Giannantonio M., Brocco C., Farina B., Di Fabio V. \& Ferro F. (2004). Interventi integrati nella schizofrenia: uno studio controllato sul contributo della terapia di gruppo [Integrated treatment for chronic schizophrenic patients: a controlled study on group psychotherapy supply]. Rivista di Psichiatria 39, 198-207.

Di Lorenzo R., Paguni R., Vasta A., Forghieri M. \& Curci P. (2005). Modalita di espressione e di funzionamento del gruppo terapeutico in un presidio psichiatrico di diagnosi e cura [Different expression and functioning of a psychotherapic group in a psychiatric ward for acute patients]. Psichiatria e Psicoterapia 24, 216-230.

Di Michele V., Bolino F., Roncone R. \& Casacchia M. (2005). Trattamento della schizofrenia con antipsicotici di prima e seconda generazione: Uno studio naturalistico a lungo termine / Treatment of schizophrenia with first and second generation antipsychotic drugs. A long term naturalistic study. Psichiatria e Psicoterapia 24, 133141.

Di Pietro G., Morlino M., Grimaldi M., Coppola N. \& Valoroso L. (2005). Disturbi dell'Alimentazione in primary care: rilevazione di casi "a rischio" di Anoressia e Bulimia con la collaborazione dei Medici di Medicina Generale dell'area napoletana. Rivista di Psichiatria 40, 276-280.

Faravelli C., Abrardi L., Bartolozzi D., Cecchi C., Cosci F., D’adamo D., Lo Iacono B., Ravaldi C., Scarpato M. A., Truglia E. \& Rosi S. (2004a). The Sesto Fiorentino study: background, methods and preliminary results. Lifetime prevalence of psychiatric disorders in an Italian community sample using clinical interviewers. Psychotherapy and Psychosomatics 73, 216-225.
Faravelli C., Abrardi L., Bartolozzi D., Cecchi C., Cosci F., D'adamo D., Lo Iacono B., Ravaldi C., Scarpato M. A., Truglia E., Rossi Prodi P. M. \& Rosi S. (2004b). The Sesto Fiorentino study: point and one-year prevalences of psychiatric disorders in an Italian community sample using clinical interviewers. Psychotherapy and Psychosomatics 73, 226-234.

Faravelli C., Giugni A., Salvatori S. \& Ricca V. (2004c). Psychopathology after rape. American Journal of Psychiatry 161, 1483-1485.

Faravelli C., Ravaldi C., Truglia E., Zucchi T., Cosci F. \& Ricca V. (2006). Clinical epidemiology of Eating Disorders: results from the Sesto Fiorentino Study. Psychotherapy and Psychosomatics 75, 376-383.

Farina B., Venturi P., Onofri A., Raja M., Pasquini P. \& Di Giannantonio M. (2004). Screening del disturbo post-traumatico da stress nelle popolazioni a rischio: il caso del disastro civile di Via Ventotene a Roma del 27 novembre 2001 [Screening of PTSD in risk populations: a survey on the population of 11.27.2001 Rome Ventotene street civil disaster]. Rivista di Psichiatria 39, 265-269.

Farina E., Mantovani F., Fioravanti R., Pignatti R., Chiavari L., Imbornone E., Olivotto F., Alberoni M., Mariani C. \& Nemni R. (2006). Evaluating two group programmes of cognitive training in mild-to-moderate $\mathrm{AD}$ : is there any difference between a 'global' stimulation and a 'cognitive-specific' one? Aging \& Mental Health $10,211-218$.

Fasanelli E., Miti G. \& Zanasi M. (2006). Il comportamento aggressivo in soggetti ospedalizzati con schizofrenia. Psichiatria $e$ Psicoterapia 25, 147-159.

Fassone G., Trincia V., Pasquini M., Picardi A., D'amato A., Biondi M. \& Pasquini P. (2006). Uno studio naturalistico di follow-up a 2 e 3,5 anni in pazienti con disturbi depressivi unipolari [A 2 and 3.5-year naturalistic follow-up study of patients with unipolar depressive disorders]. Rivista di Psichiatria 41, 320-325.

Favaro A., Tenconi E., Colombo G. \& Santonastaso P. (2006). Full and partial post-traumatic stress disorder among World War II prisoners of war. Psychopathology 39, 187-191.

Ferruzza E., Sale E., Mercuriali E. \& Boatto E. (2006). Il trauma tra passato e presente. Aspetti psicopatologici nei caregivers di traumatizzati cranici: un punto di vista psicodinamico. Rivista di Psichiatria $41,16-25$

Fioritti A., Ferriani E., Rucci P. \& Melega V. (2006). Characteristics of homicide perpetrators among Italian forensic hospital inmates. International Journal of Law and Psychiatry 29, 212-219.

Freilone F., Fratianni B. \& Giraudo E. (2005). Il burnout in strutture geriatriche [Burnout in geriatric institutes]. Minerva Psichiatrica $43,237-242$.

Gaddini A., Franco F., Di Lallo D. \& Biscaglia L. (2005). La schizofrenia e il ricorso al ricovero nei reparti psichiatrici per acuti del Lazio: studio di follow-up a quattro anni. [Hospitalisation for schizophrenia in acute psychiatric wards of the Lazio region: a 4-year followup study]. Epidemiologia e Psichiatria Sociale 14, 227-234.

Gaite L., Vazquez Barquero J. L., Herran A., Thornicroft G., Becker T., Sierra Biddle D., Ruggeri M., Schene A., Knapp M. \& Vazquez Bourgon J. (2005). Main determinants of Global Assessment of Functioning score in schizophrenia: a European multicenter study. Comprehensive Psychiatry 46, 440-446.

Galeazzi G. M., Delmonte S., Fakhoury W. \& Priebe S. (2004). Morale of mental health professionals in Community Mental Health Services of a Northern Italian Province. Epidemiologia e Psichiatria Sociale 13, 191-197.

Garattini L., Barbui C., Clemente R., Cornago D. \& Parazzini F. (2004). Direct costs of schizophrenia and related disorders in Italian community mental health services: a multicenter, prospective 1-year followup study. Schizophrenia Bulletin 30, 295-302.

Gigantesco A., Bertoldi S., Mosna S., Mirabella F. \& Morosini P. (2004). Gruppi di automutuoaiuto: la valutazione dei benefici dal punto di vista dei partecipanti [Mutual-help groups: the members' views of their benefits]. Rivista di Psichiatria 2004, 410-416. 
Gigantesco A., Palumbo G., Mirabella F., Pettinelli M. \& Morosini P. (2006a). Prevalence of psychiatric disorders in an Italian town: low prevalence confirmed with two different interviews. Psychotherapy and Psychosomatics 75, 170-176.

Gigantesco A., Vittorielli M., Pioli R., Falloon I. R. H., Rossi G. \& Morosini P. (2006b). The VADO Approach in Psychiatric Rehabilitation: A Randomized Controlled Trial. Psychiatric Services 57, 1778-1783.

Grassi L., Biancosino B., Marmai L., Kotrotsiou V., Zanchi P., Peron L., Marangoni C., Vanni A. \& Barbui C. (2006). Violence in psychiatric units: A 7-year Italian study of persistently assaultive patients. Social Psychiatry and Psychiatric Epidemiology 41, 698703.

Grava G., Ceroni G. B., Rucci P. \& Scudellari P. (2006). Suicidal behaviors and personality structure. Suicide and Life Threatening Behaviors 36, 569-577.

Gray R., Leese M., Bindman J., Becker T., Burti L., David A., Gournay K., Kikkert M., Koeter M., Puschner B., Schene A., Thornicroft G. \& Tansella M. (2006). Adherence therapy for people with schizophrenia: European multicentre randomised controlled trial. British Journal of Psychiatry 189, 508-514.

Grigoletti L., Amaddeo F., de Girolamo G. \& Picardi A. (2004). I costi delle strutture residenziali psichiatriche italiane. [Costs of psychiatric residential care in Italy]. Epidemiologia e Psichiatria Sociale $13,262-269$.

Grigoletti L., Amaddeo F., Grassi A., Boldrini M., Chiappelli M., Percudani M., Catapano F., Fiorillo A., Bartoli L., Bacigalupi M., Albanese P., Simonetti S., Perali F., De Agostini P., Tansella M. \& I-Psycost G. (2006). Proposta per un nuovo sistema di finanziamento dei Dipartimenti di Salute Mentale. Risultati di uno studio valutativo multicentrico nazionale. (I-psycost study) [Proposal for a new funding system for mental health departments. Results from a evaluative multicentre Italian study (I-psycost)]. Epidemiologia $e$ Psichiatria Sociale 15, 295-306.

Guaiana G., Andretta M., Corbari L., Mirandola M., Sorio A., D'Avanzo B. \& Barbui C. (2005). Antidepressant drug consumption and public health indicators in Italy, 1955 to 2000. Journal of Clinical Psychiatry 66, 750-755.

Hardoy M. C., Carta M. G., Marci A. R., Carbone F., Cadeddu M., Kovess V., Dell'osso L. \& Carpiniello B. (2005). Exposure to aircraft noise and risk of psychiatric disorders: the Elmas survey--aircraft noise and psychiatric disorders. Social Psychiatry and Psychiatric Epidemiology 40, 24-26.

Haro J. M., Novick D., Suarez D., Alonso J., Lepine J. P., Ratcliffe M., Kristensen K. H., Lepine J. P., Gasquet I., Naber D., Mavreas V. G., Murray D., Pancheri P., Slooff C. J., Teixeira J. M., Alonso J., Haro J. M., Bouson? O M., Croudace T., Jones P. B. \& Knapp M. (2006). Remission and relapse in the outpatient care of schizophrenia: Three-year results from the schizophrenia outpatient health outcomes study. Journal of Clinical Psychopharmacology 26, 571-578.

Holzinger A. \& Angermeyer M. C. (2002). Sozialpsychiatrische Forschung im deutschen Sprachraum. [Social-psychiatric research in german-speaking countries]. Psychiatrische Praxis 29, 397-410.

Holzinger A. \& Angermeyer M. C. (2003). Aktuelle Themen sozialpsychiatrischer Forschung im deutschen Sprachraum: Eine Inhaltsanalyse wissenschaftlicher Zeitschriften. [Current topics of social-psychiatric research in German speaking countries: a content analysis of scientific journals]. Psychiatrische Praxis 30, 424-437.

Kikkert M. J., Schene A. H., Koeter M. W. J., Robson D., Born A., Helm H., Nose M., Goss C., Thornicroft G. \& Gray R. J. (2006). Medication adherence in schizophrenia: Exploring patients', carers' and professionals' views. Schizophrenia Bulletin 32, 786-794.

Kovess V., Caldas De Almeida Jose M., Carta M., Dubuis J., Lacalmontie E., Pellet J., Roelandt J. L., Moreno Kustner B., Walsh D. \& Wiersma D. (2005). Professional team's choices of intervention towards problems and needs of patients suffering from schizophrenia across six European countries. European Psychiatry 20, 521-528.
Lalli N., Seta A., De Luca V. \& Innibelli V. (2006). Gli psicoterapeuti e la sindrome del burnout: un'indagine interattiva preliminare sulla percezione della diffusione, gravità e fattori di rischio [Psychotherapists and burnout syndrome: a preliminary interactive survey on the perception of diffusion, severity and risk factors]. Rivista di Psichiatria 41, 166-171.

Lasalvia A., Bonetto C., De Santi K. \& Ruggeri M. (2004). Tipologie di decorso clinico nelle persone con disturbi mentali: quale l'impatto sulla disabilita sociale e sulla qualita della vita? Uno studio longitudinale. [Patterns of clinical course in persons with mental disorders: which impact on social disability and quality of life? A longitudinal study]. Epidemiologia e Psichiatria Sociale 13, 169-180.

Lasalvia A., Bonetto C., Malchiodi F., Salvi G., Parabiaghi A., Tansella M. \& Ruggeri M. (2005). Listening to patients' needs to improve their subjective quality of life. Psychological Medicine 35, 16551665.

Lazzerini F., Spagna F., Raimondi R., Restuccia G. \& Lenzi A. (2006). Antipsicotici atipici: dropout come indicatore di efficacia [Atypical antipsychotics: drop-out as efficacy indicator]. Rivista di Psichiatria $41,388-396$.

Lewison G., Thornicroft G., Szmulker G. \& Tansella M. (2007). Fair assessment of the merits of psychiatric research. British Journal of Psychiatry 190, 314-318.

Lo Baido R., La Grutta S., Bressi C., Mauri M. \& Trombini E. (2004). Il fenomeno delle Mutilazioni Genitali Femminili (MGF): studio clinico e psicopatologico su un gruppo di immigrate in Sicilia [The Female Genital Mutilations (FGM): a clinical and psychopathological study on a group of immigrants in Sicily]. Rivista di Psichiatria $39,198-207$.

Lora A., Contartese A., Franco M., Lo Maglio M. C., Molteni E., Pallavicin A., Rasi E., Rossini M., Violanti E. \& Lanzara D. (2004). L'efficacia nella pratica delle strutture residenziali territoriali: uno studio osservazionale. [An observational study of effectiveness in community residential facilities]. Epidemiologia e Psichiatria Sociale 13, 198-208.

Lorant V., Kunst A. E., Huisman M., Costa G., Mackenbach J. \& Health E. U. W. G. O. S.-E. I. I. (2005). Socio-economic inequalities in suicide: a European comparative study. British Journal of Psychiatry $187,49-54$

Magliano L., De Rosa C., Fiorillo A., Malangone C., Guarneri M., Marasco C., Maj M. \& The Working Group of the Italian National Study on Families of Persons with S. (2004a). Beliefs of Psychiatric Nurses about Schizophrenia: A Comparison with Patients' Relatives and Psychiatrists. International Journal of Social Psychiatry 50, 319-330.

Magliano L., De Rosa C., Fiorillo A., Malangone C. \& Maj M. (2004b). Perception of patients' unpredictability and beliefs on the causes and consequences of schizophrenia- a community survey. Social Psychiatry and Psychiatric Epidemiology 39, 410-416.

Magliano L., Fiorillo A., De Rosa C., Malangone C. \& Maj M. (2004c). Beliefs about schizophrenia in Italy: a comparative nationwide survey of the general public, mental health professionals, and patients' relatives. Canadian Journal of Psychiatry 49, 322-330.

Magliano L., Fiorillo A., De Rosa C., Malangone C. \& Maj M. (2004d). Carico, atteggiamenti e sostegno sociale nelle famiglie dei pazienti con malattie fisiche di lunga durata. [Burden, attitudes and social support in the families of patients with long-term physical diseases]. Epidemiologia e Psichiatria Sociale 13, 255-261.

Magliano L., Fiorillo A., De Rosa C., Malangone C. \& Maj M. (2005a). Family burden in long-term diseases: a comparative study in schizophrenia vs. physical disorders. Social Science and Medicine 61, 313-322.

Magliano L., Fiorillo A., Malangone C., De Rosa C., Favata G., Sasso A., Prezioso M., Pezzenati L., Gentile F., Casale L., Bondi E., Test G. R., Di Lella M., Biscussi E., Degl'innocenti F., Bellini R., Di Nunzio R., Matrella L., Salmeri R., Cantone R., Gargiulo L., Esposito A., Delcuratolo V., Giannini M., Maresca L., Cavaliere G., Scandone B., Folla M., Raffaeli M., Innocente P., Dagianti F., 
Lucania S., Scorsino A., Bardicchia F., Cerullo G., Curreli R., Miscali S., Scordato M., Campo G., Mameli C., Sodde C., D'ambra L., Malacarne A. \& Maj M. (2005b). Aspetti positivi e difficolta nella diffusione degli interventi psicoeducativi familiari nella pratica clinica: uno studio multicentrico in 23 CSM italiani. [Benefits and difficulties in implementing family psychoeducational interventions for schizophrenia in mental health services: results from a multicentre Italian study]. Epidemiologia e Psichiatria Sociale 14, 235-242.

Magliano L., Fiorillo A., Malangone C., De Rosa C., Favata G., Sasso A., Prezioso M., Pezzenati L., Gentile F., Casale L., Bondi E., Test G. R., Di Lella M., Biscussi E., Degl'innocent F., Bellini R., Di Nunzio R., Matrella L., Salmeri R., Cantone R., Gargiulo L., Esposito A., Delcuratolo V., Giannini M., Maresca L., Cavaliere G., Scandone B., Folla M., Raffaeli M., Innocente P., Dagianti F., Lucania S., Scorsino A., Bardicchia F., Cerullo G., Curreli R., Miscali S., Scordato M., Campo G. \& Maj M. (2006a). Interventi psicoeducativi familiari per la schizofrenia nella pratica clinica: effetto sullo stato clinico e la disabilita dei pazienti e sul carico e le risorse familiari. [Family psychoeducational interventions for schizophrenia in routine settings: impact on patients' clinical status and social functioning and on relatives' burden and resources]. Epidemiologia e Psichiatria Sociale 15, 219-227.

Magliano L., Fiorillo A., Malangone C., De Rosa C. \& Maj M. (2006b). Implementing psychoeducational interventions in Italy for patients with schizophrenia and their families. Psychiatric Services 57, 266269.

Magliano L., Fiorillo A., Malangone C., De Rosa C. \& Maj M. (2006c). Patient functioning and family burden in a controlled, real-world trial of family psychoeducation for schizophrenia. Psychiatric Services 57, 1784-1791.

Magliano L., Fiorillo A., Malangone C., De Rosa C. \& Maj M. (2006d). Social network in long-term diseases: a comparative study in relatives of persons with schizophrenia and physical illnesses versus a sample from the general population. Social Science and Medicine 62, 1392-1402.

Majori S., Zanin G., Benvenuti K., Cristofoletti M., Tardivo S., Romano G., Trivello R. \& Baldo V. (2004). Suicidal behavior between 1996 and 2000 in the municipality of Padua (Italy). A retrospective analysis. Minerva Psichiatrica 45, 141-146.

Mangelli L., Benazzi F. \& Fava G. A. (2005). Assessing the community prevalence of bipolar spectrum symptoms by the mood disorder questionnaire. Psychotherapy and Psychosomatics 74, 120-122.

Marchiori E., Rossi L. \& Colombo G. (2004). La sindrome della donna malmenata in Italia [The battered woman syndrome in Italy. A psychological prospective study]. Minerva Psichiatrica 45, 43-54.

Marin I. \& Mezzina R. (2006). Percorsi soggettivi di guarigione. Studio pilota sui fattori di recovery in salute mentale. Rivista Sperimentale di Freniatria 130, 129-152.

Marmai R., Biancosino B., Rocchi D., Kotrotsiou V., Avramidou V. \& Grassi L. (2005). L'opinione dei pazienti sui fattori terapeutici del gruppo-cinema: uno studio pilota. Rivista di Psichiatria 40, 347352.

Martiello M. A., Cipriani F., Voller F., Buiatti E. \& Giacchi M. (2006). Epidemiologia descrittiva del suicidio in Toscana, 1988-2002. [The descriptive epidemiology of suicide in Tuscany, 1988-2002]. Epidemiologia e Psichiatria Sociale 15, 202-210.

Mazza M., Barbarino E., Capitani S., Sarchiapone M. \& De Risio S. (2004). Day hospital treatment for mood disorders. Psychiatric Services 55, 436-438.

Meijer K., Schene A., Koeter M., Knudsen H. C., Becker T., Thornicroft G., Vazquez-Barquero J. L. \& Tansella M. (2004). Needs for care of patients with schizophrenia and the consequences for their informal caregivers- results from the EPSILON multi centre study on schizophrenia. Social Psychiatry and Psychiatric Epidemiology 39, 251-258.

Meloni D., Miccinesi G., Bencini A., Conte M., Crocetti E., Zappa M. \& Ferrara M. (2006). Mortality among discharged psychiatric patients in Florence, Italy. Psychiatric Services 57, 1474-1481.
Menchetti M., Cevenini N., De Ronchi D., Quartesan R. \& Berardi D. (2006). Depression and frequent attendance in elderly primary care patients. General Hospital Psychiatry 28, 119-124.

Minnai G. P., Tondo L., Salis P., Ghiani C., Manfredi A., Paluello M. M., Baethge C. \& Baldessarini R. J. (2006). Secular trends in first hospitalizations for major mood disorders with comorbid substance use. International Journal of Neuropsychopharmacology 9, 319326.

Mirandola M., Amaddeo F., Dunn G. \& Tansella M. (2004). The effect of previous psychiatric history on the cost of care: a comparison of various regression models. Acta Psychiatrica Scandinavica 109, 132-139.

Morosini P., de Girolamo G., Picardi A. \& Di Fabio F. (2001). National Mental Health Project (Scientific coordinator: Pierluigi Morosini). Final report. [Progetto Nazionale Salute Mentale (Responsabile scientifico: Pierluigi Morosini). Rapporto conclusivo.]. Rapporti ISTISAN 01/27, 1-240. Retrieved April 4, 2007, from http://www.iss.it/ $\mathrm{publ} / \mathrm{rapp} / \mathrm{cont}$.php?id=408\&lang=1\&tipo $=5 \&$ anno $=2001$.

Morselli P. L., Elgie R. \& Cesana B. M. (2004). GAMIANEurope/BEAM survey II: Cross-national analysis of unemployment, family history, treatment satisfaction and impact of the bipolar disorder on life style. Bipolar Disorders 6, 487-497.

Paccaloni M., Pozzan T., Rimondini M. \& Zimmermann C. (2006). Le conoscenze e i bisogni informativi dei pazienti con diagnosi di schizofrenia esplorati attraverso il metodo dei focus group. [Knowledge and informative needs of patients with the diagnosis of schizophrenia, explored with focus group methods]. Epidemiologia e Psichiatria Sociale 15, 128-137.

Pacitti F., Iannitelli A. \& Bersani G. (2005). Studio naturalistico sull'impiego degli antipsicotici nella formulazione long-acting negli SPDC di Roma e del Lazio. Rivista di Psichiatria 40, 220-233.

Pallanti S., Quercioli L. \& Hollander E. (2004). Social anxiety in outpatients with schizophrenia: a relevant cause of disability. American Journal of Psychiatry 161, 53-58.

Parabiaghi A., Barbato A., D'Avanzo B., Erlicher A. \& Lora A. (2005). Assessing reliable and clinically significant change on Health of the Nation Outcome Scales: method for displaying longitudinal data. Australian and New Zealand Journal of Psychiatry 39, 719-725.

Parabiaghi A., Bonetto C., Ruggeri M., Lasalvia A. \& Leese M. (2006). Severe and persistent mental illness: a useful definition for prioritizing community-based mental health service interventions. Social Psychiatry and Psychiatric Epidemiology 41, 457-463.

Pasquali M., De Sanctis R. \& Spoletini A. (2004). Il Programma Gestione del Rischio Clinico: l'errore come occasione di crescita. Risultati preliminari in un Servizio Psichiatrico di Diagnosi e Cura [The Risk Management Program: the error as an opportunity of professional growth.Preliminary outcomes in a Hospital Psychiatric Unit]. Rivista di Psichiatria 39, 45-57.

Pavia M., Nicotera G., Scaramuzza G. \& Angelillo I. F. (2005). Suicide mortality in Southern Italy: 1998-2002. Psychiatry Research 134, 275-279.

Percudani M., Barbui C., Beecham J. \& Knapp M. (2004a). Routine outcome monitoring in clinical practice: service and non-service costs of psychiatric patients attending a Community Mental Health Centre in Italy. European Psychiatry 19, 469-477.

Percudani M., Barbui C., Fortino I. \& Petrovich L. (2004b). Antidepressant drug use in Lombardy, Italy: a population-based study. Journal of Affective Disorders 83, 169-175.

Percudani M., Barbui C., Fortino I. \& Petrovich L. (2004c). Antipsychotic drug prescribing in the elderly is cause for concern. International Clinical Psychopharmacology 19, 347-350.

Percudani M., Barbui C., Fortino I. \& Petrovich L. (2005a). Antidepressant drug prescribing among elderly subjects: a population-based study. International Journal of Geriatric Psychiatry 20, 113-118.

Percudani M., Barbui C., Fortino I. \& Petrovich L. (2005b). Epidemiology of first- and second-generation antipsychotic agents in Lombardy, Italy. Pharmacopsychiatry 38, 128-131. 
Percudani M., Barbui C., Fortino I., Tansella M. \& Petrovich L. (2006). La prescrizione di antidepressivi e antipsicotici nella popolazione generale in Lombardia. [Antidepressant and antipsychotic drug prescribing in Lombardy]. Epidemiologia e Psichiatria Sociale 15, 59-70.

Picardi A., de Girolamo G., Santone G., Falloon I., Fioritti A., Micciolo R., Morosini P. \& Zanalda E. (2006a). The Environment and Staff of Residential Facilities: Findings from the Italian "Progres" National Survey. Community Mental Health Journal 42, 263-279.

Picardi A., Rucci P., de Girolamo G., Santone G., Borsetti G. \& Morosini P. (2006b). The quality of life of the mentally ill living in residential facilities: Findings from a national survey in Italy. European Archives of Psychiatry and Clinical Neuroscience 256, 372-81.

Pigato G., Vignaga F. \& Pavan L. (2005). Uso dei neurolettici convenzionali o atipici nella prima ospedalizzazione per psicosi acuta. Rivista di Psichiatria 40, 207-215.

Pizzichi E., Corradetti V., Gherardelli S. \& Satta L. (2005). Rilevazione della sindrome del burnout nei reparti SPDC, Nefrologia, Dialisi dell'Ospedale Sandro Pertini di Roma. Rivista di Psichiatria 40, 8288.

Pompili M., Rinaldi G., Lester D., Girardi P., Ruberto A. \& Tatarelli R. (2006). Hopelessness and suicide risk emerge in psychiatric nurses suffering from burnout and using specific defense mechanisms. Archives of Psychiatric Nursing 20, 135-143.

Pozzi G., Frustaci A., Janiri L. \& Di Giannantonio M. (2006). The challenge of psychiatric comorbidity to the public services for drug dependence in Italy: A national survey. Drug and Alcohol Dependence 82, 224-230.

Preti A., Incani E., Camboni M. V., Petretto D. R. \& Masala C. (2006). Sexual abuse and eating disorder symptoms: the mediator role of bodily dissatisfaction. Comprehensive Psychiatry 47, 475-481.

Priebe S. \& Hoffmann K. (2002). Sozialpsychiatrie und gemeindenahe Versorgung. In Kompendium Psychiatrie Psychotherapie Psychosomatishe Medizin (ed. H. J. Freyberger, W. Schneider and R. D. Stieglitz), pp. 339-348. Karger: Basel.

Priebe S., Badesconyi A., Fioritti A., Hansson L., Kilian R., TorresGonzales F., Turner T. \& Wiersma D. (2005). Reinstitutionalisation in mental health care: comparison of data on service provision from six European countries. British Medical Journal 330, 123-126.

Puschner B., Born A., Giebler A., Helm H., Leese M., Bindman J. P., Gray R. J., Schene A., Kikkert M., Burti L., Marrella G. \& Becker T. (2006). Adherence to Medication and Quality of Life in People With Schizophrenia: Results of a European Multicenter Study. Journal of Nervous and Mental Disease 194, 746-752.

Quaglio G., Lugoboni F., Pajusco B., Fornasiero A., Lechi A., Mezzelani P., Pattaro C. \& Des Jarlais D.C. (2004). Heterosexual relationships among heroin users in Italy. Drug and Alcohol Dependence 75, 207-213.

Rimondini M., Del Piccolo L., Goss C., Mazzi M., Paccaloni M. \& Zimmermann C. (2006). Communication skills in psychiatry residents-- how do they handle patient concerns? An application of sequence analysis to interviews with simulated patients. Psychotherapy and Psychosomatics 75, 161-169.

Rinaldi P., Spazzafumo L., Mastriforti R., Mattioli P., Marvardi M., Polidori M. C., Cherubini A., Abate G., Bartorelli L., Bonaiuto S., Capurso A., Cucinotta D., Gallucci M., Giordano M., Martorelli M., Masaraki G., Nieddu A., Pettenati C., Putzu P., Tammaro V. A., Tomassini P. F., Vergani C., Senin U. \& Mecocci P. (2005). Predictors of high level of burden and distress in caregivers of demented patients: results of an Italian multicenter study. International Journal of Geriatric Psychiatry 20, 168-174.

Robone C., Pasquini M. \& Biondi M. (2004). Drop-out e dati demografici nei Disturbi d'Ansia [Age and drop-out from treatment in Anxiety Disorders]. Rivista di Psichiatria 39, 101-104.

Rocca P., Bellino S., Calvarese P., Marchiaro L., Patria L., Rasetti R. \& Bogetto F. (2005). Depressive and negative symptoms in schizophrenia: Different effects on clinical features. Comprehensive Psychiatry 46, 304-310.
Rossi A., Amaddeo F., Sandri M. \& Tansella M. (2005a). Determinants of once-only contact in a community-based psychiatric service. Social Psychiatry and Psychiatric Epidemiology 40, 50-56.

Rossi A., Morgan V., Amaddeo F., Sandri M., Tansella M. \& Jablensky A. (2005b). Psychiatric out-patients seen once only in South Verona and Western Australia: a comparative case-register study. Australian and New Zealand Journal of Psychiatry 39, 414-422.

Rossi A., Sandri M., Bianco M., Marsilio A., Tansella M. \& Amaddeo F. (2006). Factors associated with clinicians' dispositions in an outpatient psychiatric department. Social Psychiatry and Psychiatric Epidemiology 41, 832-840.

Ruggeri M., Bisoffi G., Lasalvia A., Amaddeo F., Bonetto C. \& Biggeri A. (2004a). A longitudinal evaluation of two-year outcome in a community-based mental health service using graphical chain models. The South-Verona Outcome Project 9. International Journal of Methods in Psychiatric Research 13, 10-23.

Ruggeri M., Lasalvia A., Tansella M., Bonetto C., Abate M., Thornicroft G., Allevi L. \& Ognibene P. (2004b). Heterogeneity of outcomes in schizophrenia. 3-year follow-up of treated prevalent cases. British Journal of Psychiatry 184, 48-57.

Ruggeri M., Leese M., Slade M., Bonizzato P., Fontecedro L. \& Tansella M. (2004c). Demographic, clinical, social and service variables associated with higher needs for care in community psychiatric service patients. The South Verona Outcome Project 8. Social Psychiatry and Psychiatric Epidemiology 39, 60-68.

Ruggeri M., Nose M., Bonetto C., Cristofalo D., Lasalvia A., Salvi G., Stefani B., Malchiodi F. \& Tansella M. (2005). Changes and predictors of change in objective and subjective quality of life: multiwave follow-up study in community psychiatric practice. British Journal of Psychiatry 187, 121-130.

Ruggeri M., Salvi G., Perwanger V., Phelan M., Pellegrini N. \& Parabiaghi A. (2006). Satisfaction with community and hospitalbased emergency services amongst severely mentally ill service users: A comparison study in South-Verona and South-London. Social Psychiatry and Psychiatric Epidemiology 41, 302-309.

Saltini A., Mazzi M., Del Piccolo L. \& Zimmermann C. (2004). Decisional strategies for the attribution of emotional distress in primary care. Psychological Medicine 34, 729-739.

Salvador-Carulla L., Tibaldi G., Johnson S., Scala E., Romero C. \& Munizza C. (2005). Patterns of mental health service utilisation in Italy and Spain--an investigation using the European Service Mapping Schedule. Social Psychiatry and Psychiatric Epidemiology 40, 149-159.

Sangiorgio P. (2004). Emergenze psichiatriche e psichiatria d'urgenza. Studio di follow up 1999-2001 nel Lazio: Considerazioni e proposte [Psychiatric emergencies and emergency psychiatry: Follow-up of 1999-2001 study in Lazio: Considerations and proposals]. Psichiatria e Psicoterapia 23, 126-141.

Santone G., de Girolamo G., Falloon I., Fioritti A., Micciolo R., Picardi A. \& Zanalda E. (2005). The process of care in residential facilities-a national survey in Italy. Social Psychiatry and Psychiatric Epidemiology 40, 540-550.

Saxena S., Van Ommeren M., Lora A. \& Saraceno B. (2006). Monitoring of mental health systems and services: comparison of four existing indicator schemes. Social Psychiatry and Psychiatric Epidemiology 41, 488-497.

Scarnera P., Bosco A. \& Urbano M. L. (2006). La prevenzione del burnout nelle attività terapeutico riabilitative psichiatriche: un'esperienza applicativa italiana [Prevention of burnout in psychiatric therapeutic-rehabilitative activities: an italian application]. Rivista di Psichiatria 41, 378-387.

Schiavone P., Dorz S., Conforti D., Scarso C. \& Borgherini G. (2006). The clinical implications of DSM-IV personality disorder comorbidity in depressed inpatient: A replication study in an Italian setting. Journal of Personality Disorders 20, 1-8.

Scocco P., Rapattoni M. \& Fantoni G. (2006a). Nursing home institutionalization: a source of eustress or distress for the elderly? International Journal of Geriatric Psychiatry 21, 281-287. 
Scocco P., Rapattoni M., Fantoni G., Galuppo M., De Biasi F., de Girolamo G. \& Pavan L. (2006b). Suicidal behaviour in nursing homes: a survey in a region of north-east Italy. International Journal of Geriatric Psychiatry 21, 307-311.

Scuccimarra G., Velotti R., Canfora F., Facciuto A. \& Mellucci S. (2005). Il ruolo dei fattori ambientali sullo sviluppo delle competenze adattive nei soggetti con disabilità intellettive [The role of the environmental factors on the development of adaptive skills in intellectual disabilities subjects]. Epidemiologia e Psichiatria Sociale $14,108-115$.

Slade M., Leese M., Ruggeri M., Kuipers E., Tansella M. \& Thornicroft G. (2004). Does meeting needs improve quality of life? Psychotherapy and Psychosomatics 73, 183-189.

Slade M., McCrone P., Kuipers E., Leese M., Cahill S., Parabiaghi A., Priebe S. \& Thornicroft G. (2006). Use of standardised outcome measures in adult mental health services: Randomised controlled trial. British Journal of Psychiatry 189, 330-336.

Soscia F., Ruberto A., Girardi P., Torricelli F. D., Mannu J., Recchi G., Moinzadeh Z., Smeriglio G., Narracci A., Lonta P., Antonelli E., Ceppi F., Uriati P., Perilli S., Rocco S., Di Matteo L., Kotzalidis G. D. \& Tatarelli R. (2005). Approccio evidence-based alla valutazione del trattamento comunitario: Outcome di pazienti psichiatrici nelle comunita terapeutico-riabilitative del lazio [Evidence-based approach to the assessment of community treatment: Outcome of psychiatric patients in therapeutic-rehabilitative communities in the Latium region, Italy]. Psichiatria e Psicoterapia 24, 273-290.

Tarricone I., Leese M., Szmukler G. I., Bassi M. \& Berardi D. (2006). The experience of carers of patients with severe mental illness: a comparison between London and Bologna. European Psychiatry 21, 93-101.

Tello J. E., Jones J., Bonizzato P., Mazzi M., Amaddeo F. \& Tansella M. (2005a). A census-based socio-economic status (SES) index as a tool to examine the relationship between mental health services use and deprivation. Social Science and Medicine 61, 2096-2105.

Tello J. E., Mazzi M., Tansella M., Bonizzato P., Jones J. \& Amaddeo F. (2005b). Does socioeconomic status affect the use of communitybased psychiatric services? A South Verona case register study. Acta Psychiatrica Scandinavica 112, 215-223.

Thornicroft G., Tansella M., Becker T., Knapp M., Leese M., Schene A. \& Vazquez-Barquero J. L. (2004). The personal impact of schizophrenia in Europe. Schizophrenia Research 69, 125-132.

Tomasi R., de Girolamo G., Santone G., Picardi A., Micciolo R., Semisa D. \& Fava S. (2005). La prescrizione di psicofarmaci nelle strutture residenziali italiane [Drug prescription in Italian Residential Facilities]. Epidemiologia e Psichiatria Sociale 14, 7790.

Tomasi R., de Girolamo G., Santone G., Picardi A., Micciolo R., Semisa D. \& Fava S. (2006 ). The prescription of psychotropic drugs in psychiatric residential facilities: a national survey in Italy. Acta Psychiatrica Scandinavica 113, 212-23.

Tomei G., Cherubini E., Ciarrocca M., Biondi M., Rosati M. V., Tarsitani L., Capozzella A., Monti C. \& Tomei F. (2006). Short communication: Assessment of subjective stress in the municipal police force at the start and at the end of the shift. Stress and Health 22, 239-247.

Trequattrini A., Guidi L., Spadoni L., Mezzetti M. \& Ciappi F. (2004). Studio osservazionale per la valutazione del carico assistenziale e familiare della demenza in pazienti con accesso a un centro diurno [Observational, evaluative study of assisted and familial care burdens of dementia in patients with access to an adult daycare center]. Psichiatria e Psicoterapia 23, 142-150.

Van Os J. I. M., Altamura A. C., Bobes J., Gerlach J. E. S., Hellewell J. S. E., Kasper S., Naber D. \& Robert P. (2004). Evaluation of the Two-Way Communication Checklist as a clinical intervention: Results of a multinational, randomised controlled trial. British Journal of Psychiatry 184, 79-83.

Van Weeghel J., Van Audenhove C., Colucci M., Garanis Papadatos T., Liegeois A., Mcculloch A., Muijen M., Norcio B., Ploumbidis D. \& Bauduin D. (2005). The components of good community care for people with severe mental illnesses: Views of stakeholders in five European countries. Psychiatric Rehabilitation Journal 28, 274-281.

Vanni A., Biancosino B., Marmai L., Zucconi M., Peron L., L.C., Marangoni C. \& Grassi L. (2004). Correlati psicobiologici dei comportamenti aggressivi in pazienti psichiatrici: uno studio controllato [Psychobiological concomitants of aggressive behaviour among psychiatric impatients: a control study]. Rivista di Psichiatria 39, 40-44.

Veltro F., Cuccaro A., Vendittelli N., Oricchio I., Scinto A., Dragani A. \& Morosini P. (2005a). Valutazione di efficacia di un intervento strutturato cognitivo-comportamentale di gruppo per pazienti ricoverati. Rivista di Psichiatria 40, 353-359.

Veltro F., Raimondo A., Porzio C., Nugnes T. \& Ciampone V. (2005b). Un'indagine sul pregiudizio e sugli stereotipi della malattia mentale in due comunita che differiscono per la "presenza/assenza" di strutture psichiatriche residenziali. [A survey on the prejudice and the stereotypes of mental illness in two communities with or without psychiatric Residential Facilities]. Epidemiologia e Psichiatria Sociale 14, 170-176.

Veltro F., Magliano L., Morosini P., Fasulo E., Pedicini G., Cascavilla I., Falloon I. \& Dsm-Bn1. G. D. L. (2006). Randomised controlled trial of a behavioural family intervention: 1 year and11-years follow-up. Epidemiologia e Psichiatria Sociale 15, 44-51.

Zammuner V. L. \& Galli C. (2005). Wellbeing: causes and consequences of emotion regulation in work settings. International Review of Psychiatry 17, 355-364.

Zanetti T., Cenci L., Favaro A. \& Santonastaso P. (2005). Evoluzione a medio termine dell'Anoressia Nervosa in pazienti che hanno abbandonato la terapia [Middle term outcome in Anorexia Nervosa outpatients who dropped out from therapy]. Rivista di Psichiatria 40, 149155.

Zeppegno P., Manzetti E., Valsesia R., Siliquini R., Ammirata G., De Donatis O., Usai C. \& Torre E. (2005). Differences in suicide behaviour in the elderly: a study in two provinces of Northern Italy. International Journal of Geriatric Psychiatry 20, 769-775. 